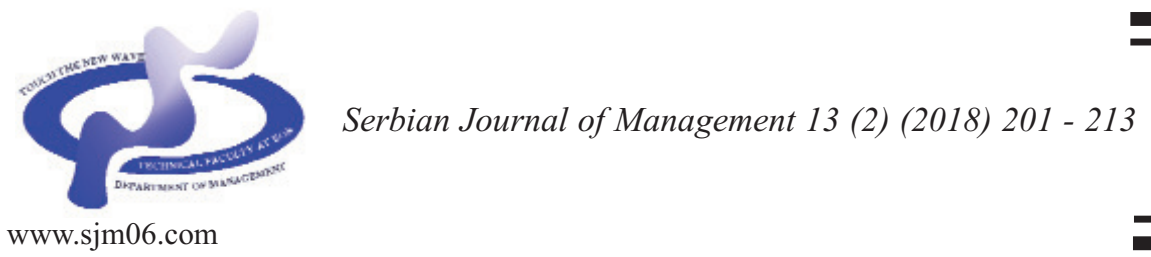

\title{
MEASURING THE EFFICIENCY OF INDIAN CEMENT COMPANIES UTILIZING DATA ENVELOPMENT ANALYSIS DURING THE PRE AND POST RECESSION PERIOD
}

\author{
Arindam Banerjee* \\ Department of Management, Jawahari Devi Birla Institute, \\ Moira Street 1, Pin: 700017, Kolkata, India
}

(Received 28 July 2017; accepted 11 April 2018)

\begin{abstract}
The present research work was conducted to measure the efficiency of the cement companies in Indian Scenario by utilizing the concept of Data Envelopment Analysis during the pre and post period of recession during the recent global turmoil. In the present study two outputs (related to profit and sales) and three inputs related to cost are taken into consideration .Input oriented variable return to scale has been used for this paper. Linear program has been developed to measure the efficiency and super efficiency scores of the different cement companies. A further endeavour has been made in this paper to understand if recession really did have any impact on the cement industry by utilizing spearman rank correlation technique.
\end{abstract}

Keywords: data envelopment analysis, decision making units, efficiency, recession, cement, India

\section{INTRODUCTION}

Efficiency has been defined as the ratio between output and input. In order to optimize the efficiency the organization must either maximize the output (keeping the input constant) or minimize the inputs (keeping the output constant). The former method is known as Output oriented approach and the later is known as the Input oriented approach. Generally, organization is exposed to an environment that is extremely complex and dynamic, being burdened with a series of influences which, sometimes knowingly and sometimes unconsciously, includes into the decision-making process (Popovic et al, 2018). Efficiency can be easily measured if there is one input and one output. But the problem arises if there is more than one inputs and outputs. Data envelopment analysis provides solution to such problems. It is an operation research technique developed by Charnes, Coopers and Rhodes (in 1978) to measure the efficiency of DMUs (Decision Making Units) in case of multiple inputs or outputs. In case of multiple inputs and outputs, Charnes et al. (1978) have defined efficiency

\footnotetext{
* Corresponding author: dr.arindam.cma@gmail.com
}

DOI: $10.5937 /$ sjm13-14685 
as ratio between the weighted sum of outputs and weighted sum of inputs. Weights are being assigned on basis of suitable programming. They basically assumed constant return to scale. Later on Banker et al (1984) in their paper established the variable return to scale which encompassed both the increasing as well as decreasing return to scale. Hence to achieve optimum efficiency, data envelopment analysis can resort to Input or Output oriented approach which can be explained by either constant return to scale or variable return to scale. In this paper input oriented variable return to scale approach has been utilized.

In this paper two outputs and three inputs are taken into consideration. The two outputs relate to Sales and Profit. PBDIT (Profit before Depreciation, Interest and Tax) has been taken as a proxy for profit. The entire period of our study has been segregated into Pre Recession period from 2004-05 to 200607 and Post Recession period from 2007-08 to 2009-10. The Post recession period included the recession period. Recession does have an impact on economy with overall decrease in employment, production as well as GDP of a country. Recession did have negative impact on Indian economy like a) Index of Industrial production (IIP) reflected a drastic fall from $11.9 \%$ in 200607 to $8.7 \%$ in $2007-08$ and again to $3.2 \%$ in 2008-09 b) GDP at factor cost reduced from 9.6\% in 2006-07 to $6.8 \%$ in 2008-09. c) BSE Sensex which is a barometer to test the health of Indian economy reflected a fall from 20000 points in December 2007 to little more than 8000 points in March 2009. One of the greatest impact on the Indian stock market was the withdrawal of funds by FIIs to the extent of 8000 US million\$ during April to December 2008. The main purpose of conducting this study was to understand if recession did have any impact on the performance of the Indian Cement companies during the Post recession period compared to Pre recession period. Linear program was developed to attain the above objective.

\section{LITERATURE REVIEW}

Data Envelopment analysis is a non parametric approach to measure the efficiency of the decision making units. Banker, Charnes and Cooper (1984) in their paper have developed mathematical programming to measure the operational efficiency of the decision making units. They developed the model with variable return to scale which was devoid of the scale effects. The past paper of Banker, Charnes and Cooper was referred so as to formulate the linear program to compute the efficiency score for the Indian cement companies. The formula was:

\section{Min Theta (Objective Function)}

Subject to the following constraints:

$$
\begin{aligned}
& \sum_{\substack{j=1 \\
n}}^{n} w_{j} x_{i}^{j} \leq \theta x_{i}^{t} ; i=1,2,3 \ldots m \\
& \sum_{\substack{j=1 \\
n}}^{n} w_{j} y_{r}^{j} \geq y_{r}^{t} ; r=1,2,3 \ldots s \\
& \sum_{j=1}^{n} w_{j}=1 ; \\
& W_{j \geq 0}(j=1,2,3 \ldots n)
\end{aligned}
$$

In the above, $w_{j}=$ weight of $\mathrm{j}^{\text {th }}$ decision making unit

$\mathrm{x}_{\mathrm{i}}^{\mathrm{j}}=\mathrm{i}^{\text {th }}$ input for $\mathrm{j}^{\text {th }}$ decision making unit $\mathrm{y}_{\mathrm{r}} \mathrm{j}^{\mathrm{s}}=\mathrm{r}^{\text {th }}$ output for $\mathrm{j}^{\text {th }}$ decision making unit 
$\mathrm{x}_{\mathrm{i}}{ }^{\mathrm{t}}=\mathrm{i}^{\text {th }}$ input for $\mathrm{t}^{\text {th }}$ decision making unit

$\mathrm{y}_{\mathrm{r}}{ }^{\mathrm{t}}=\mathrm{r}^{\text {th }}$ output for $\mathrm{t}^{\text {th }}$ decision making unit

Theta = use to calculate the efficiency; $\mathrm{m}=$ inputs; $\mathrm{s}=$ outputs

Andersen and Peterson (1993) in their paper have made an attempt to provide a guideline to rank the efficient units and also help in comparing the ranks obtained on basis of parametric methods. The paper had proposed a super efficient DEA model to replace the traditional approach to DEA model. Super efficiency analysis was developed by Anderson and Peterson. The past work of Anderson and Peterson was referred as to formulate the linear program to compute the super efficiency score for the Indian cement companies whose efficiency score was 1 .

Min Theta (Objective Function)

Subject to the following constraints:

$$
\begin{aligned}
& \sum_{j=1}^{n} w_{j} x_{i}^{j} \leq \theta x_{i}^{t} ; i=1,2,3 \ldots m \\
& \sum_{\substack{j=1 \\
n}}^{n} w_{j} y_{r}^{j} \geq y_{r}^{t} ; r=1,2,3 \ldots s \\
& \sum_{j=1}^{n} w_{j}=1 ;
\end{aligned}
$$

$\mathrm{W}_{\mathrm{j}} \geq 0(\mathrm{j}=1,2,3,4 \ldots \ldots \mathrm{n})$, where $\mathrm{j}$ is not equal to $t$

The other past literatures reviewed by me for the present study are as follows:

Karimzadeh (2012) in his paper have tried to investigate into the efficiency of the Indian commercial banks by applying the concept of Data envelopment analysis. It was concluded from the study that the public sector banks performed better than private sector banks.

Nandkumar and Singh (2014) in their paper have tried to measure the technical efficiency of the commercial banks in Indian scenario. It was deduced from the study that the performance of the private sector banks was better than the public sector banks during the period of the study.

Tandon and Malhotra (2014) have made an attempt in their paper to measure the technical, pure and scale efficiency of the Indian commercial banks. It was concluded from the study that there was very less significant difference between the efficiency scores obtained by the public, private and foreign banks.

Tehrani, Megharagan and Golkani (2012) have tried to evaluate the corporate performance of the selected companies through data envelopment analysis taking into consideration profitability ratio as output in the analysis.

Charles, Kumar, Zegarra and Avolio (2011) have tried to measure the efficiency of the Peruvian banks through application of data envelopment analysis. Overall it was observed that multinational banks were better performers that the regional banks in Peru.

Feroz, Kim and Raab (2003) have made an attempt to understand the advantages of applying data envelopment analysis over ratio analysis to measure the efficiency of the firms.

\section{RESEARCH METHODOLOGY}

The present study has been conducted taking into consideration two output and three inputs. In this study two outputs relate to sales and profit. PBDITA (Profit before depreciation, interest, tax and amortization) has been taken as a proxy for profit. Sales are basically the turnover of the company. All 
the three inputs taken into consideration for the study relate to the cost structure of the company. The data (related to the above five variables) for the nine cement companies are derived from CMIE Prowess software. These nine cement companies are derived BSE 500 index in India as per their turnover. Lingo 13.0 and SPSS 20.0 has been used for analysis purpose.

\section{OBJECTIVES OF THE STUDY}

The major objectives of this study are as follows:

1) To develop a linear program utilizing the Data envelopment analysis to compute the efficiency and super efficiency scores of the Indian cement companies during the Pre and Post period of recession.

2) To rank the different companies as per their efficiency and super efficiency scores during the Pre and Post period of recession.

3) To investigate if recession had any impact on the performance of the Indian cement companies during the post period of recession compared to the pre recession period.

\section{RESULTS}

In the present study three inputs i.e. i) Raw Materials, store and spares ii) Power, fuel and water charges iii)Compensation to the employees and two outputs i.e. i) Sales and ii) PBDITA (Profit before depreciation, interest, tax and amortization) is taken into consideration. The entire analysis is segregated between Pre recession period (2004-05 to 2006-07) and Post recession period (2007-08 to 2009-10) so as to capture any changes occurring in relation to the efficiency evaluation of the Indian cement industry during these two periods.

\subsection{Pre recession period (2004-05 to 2006-07)}

Each and every company in the cement industry is known as the Decision making units for the study. A total of nine cement companies/Decision making units that has been taken into consideration for the study. The average of the all the five variables (two outputs and three inputs) during the 2004-05 to 2006-07 periods is reflected in Table 1.

Data envelopment analysis is basically a non-parametric approach of linear

Table 1. Data related to Inputs and Outputs for DEA (Pre Recession period)

\begin{tabular}{|c|c|c|c|c|c|c|}
\hline SI No & Name of the Company & Sales & PBDITA & \begin{tabular}{l}
\multicolumn{1}{c}{ Raw } \\
materials, \\
stores \& \\
spares
\end{tabular} & \begin{tabular}{l}
\multicolumn{1}{c}{ Power, } \\
fuel $\&$ \\
water \\
charges
\end{tabular} & $\begin{array}{l}\text { Compensation } \\
\text { to employees }\end{array}$ \\
\hline DMU1 & A C C Ltd. & 49467 & 9979 & 18584 & 7570 & 4368 \\
\hline DMU2 & Ambuja Cements Ltd. & 57144 & 17116 & 13898 & 9328 & 3834 \\
\hline DMU3 & India Cements Ltd. & 19694 & 4083 & 6118 & 3973 & 2186 \\
\hline DMU4 & J K Cement Ltd. & 10237 & 1720 & 2340 & 2139 & 700 \\
\hline DMU5 & J K Lakshmi Cement Ltd. & 7692 & 1640 & 2759 & 1600 & 834 \\
\hline DMU6 & Prism Cement Ltd. & 6998 & 1905 & 2199 & 1422 & 588 \\
\hline DMU7 & Ramco Cements Ltd. & 12953 & 3158 & 4189 & 2292 & 1159 \\
\hline DMU8 & Shree Cement Ltd. & 10502 & 3337 & 3363 & 1507 & 784 \\
\hline DMU9 & Ultratech Cement Ltd. & 41161 & 7779 & 14744 & 8342 & 3444 \\
\hline
\end{tabular}


programming. Linear program has been developed to measure the efficiency score of the nine decision making units in our study. To develop the linear program the information are been derived from Table 1. A sample of linear program developed for ACC ltd is given in Appendix A. Input oriented variable return to scale approach has been utilized in this paper. Thus the objective was to minimize the theta. Then the linear program was run in Lingo 13.0 to calculate the efficiency score. Those companies whose efficiency scores were 1, super efficiency score were computed by again reformulating the linear program. When the linear program developed for ACC ltd was run in Lingo the efficiency score was 1 . Hence again the super efficiency score was computed by reformulating the linear program. The linear program used to compute the super efficiency score of ACC ltd is given in Appendix B. The efficiency and super efficiency output of ACC ltd after running the program in Lingo is provided in Appendix C and Appendix D.

Similar exercise was conducted for the other eight decision making units. The efficiency and super efficiency score computed after running the program in Lingo is reflected in Table 2. Those decision making units whose efficiency scores were below 1 has a scope of improvement. Then the DMUs were ranked as per their scores. Those companies whose efficiency scores were 1, super efficiency scores were taken into consideration for ranking them. The ranks obtained by the different DMUs along with their scores are provided in Table 2.

\subsection{Post Recession period (2007-08 to 2009-10)}

Similar to the Pre recession period, the average of the five variables (two outputs and three inputs) during the three financial years (of Post recession period) from 200708 to 2009-10 is reflected in Table 3.

Data envelopment analysis has been utilized so as to formulate the linear program for the cement companies during the post recession period to compute the efficiency scores of the nine decision making units using the information available from Table 3. Those companies whose efficiency scores were 1, super efficiency score were computed for the post recession period similar to the pre recession period.

The efficiency and super efficiency score thus computed of the different cement companies are shown in Table 4 after running the program in Lingo 13.0. Then the ranks were allocated to the different companies as per their efficiency and super efficiency scores obtained. The rank along

Table 2. Efficiency and Super Efficiency Score of the Cement Companies in Pre Recession period

\begin{tabular}{cllll}
\hline \multicolumn{1}{c}{ SI No } & Name of Company & Efficiency Score & Super Efficiency & Rank \\
\hline DMU1 & A C C Ltd. & 1 & 1.062 & 4 \\
DMU2 & Ambuja Cements Ltd. & 1 & 1.046 & 5 \\
DMU3 & India Cements Ltd. & .830 & ---- & 8 \\
DMU4 & J K Cement Ltd. & 1 & 1.262 & 3 \\
DMU5 & J K Lakshmi Cement & .899 & ----- & 6 \\
DMU6 & Prism Cement Ltd. & 1 & 1.276 & 2 \\
DMU7 & Ramco Cements Ltd. & .891 & ---- & 7 \\
DMU8 & Shree Cement Ltd. & 1 & 1.437 & 1 \\
DMU9 & Ultratech Cement ltd & .815 &.---- & 9 \\
\hline
\end{tabular}


with the different companies' efficiency and super efficiency scores are shown in Table 4.

Spearman rank correlation technique has been utilized so as to investigate if there was any correlation existing among the ranks obtained by the cement companies during the Pre and Post period of recession. This was done to basically understand if the recession period had any effect on the performance of the cement industry during the post recession period compared to the pre recession period. The ranks have been obtained from Table 2 for Pre recession period and Table 4 for Post recession period. The rank obtained by the cement companies during the pre and post period of recession has been shown in a combined manner in Table 5.
The graphical representation of the ranks obtained by the companies during the pre and post period of recession is represented by Figure 1.

SPSS 20.0 has been utilized so as compute the Spearman ranks correlation. It is observed from Table 6 below that Spearman rank correlation is found to be 633.

An attempt has been made in this paper to understand the descriptive statistics of the five different variables taken into consideration for this study during the Pre and Post period of recession. This was done to understand how well the companies have performed during the Pre as well as Post period of recession. SPSS 20.0 has been

Table 3. Data related to Inputs and Outputs for DEA (Post Recession period)

\begin{tabular}{ccccccc}
\hline & Name of the Company & Sales & PBDITA & $\begin{array}{c}\text { Raw } \\
\text { materials, } \\
\text { stores \& } \\
\text { Spares }\end{array}$ & $\begin{array}{c}\text { Power, } \\
\text { fuel \& } \\
\text { water } \\
\text { charges }\end{array}$ & $\begin{array}{c}\text { Compensation to } \\
\text { employees }\end{array}$ \\
\hline DMU1 & A C C Ltd. & 86405 & 24251 & 72331 & 8343 & 14607 \\
DMU2 & Ambuja Cements Ltd. & 76798 & 24474 & 62387 & 10775 & 12560 \\
DMU3 & India Cements Ltd. & 39252 & 10394 & 34722 & 3404 & 8607 \\
DMU4 & J K Cement Ltd. & 20015 & 4174 & 17966 & 2049 & 3724 \\
DMU5 & J K Lakshmi Cement & 14919 & 4006 & 12765 & 2163 & 2830 \\
DMU6 & Prism Cement Ltd. & 16015 & 3517 & 14088 & 3003 & 2281 \\
DMU7 & Ramco Cements Ltd. & 27539 & 8100 & 23927 & 3809 & 5370 \\
DMU8 & Shree Cement Ltd. & 32815 & 11936 & 27782 & 4850 & 5278 \\
DMU9 & Ultratech Cement Ltd. & 71680 & 19204 & 61801 & 11865 & 14721 \\
\hline
\end{tabular}

Table 4. Efficiency and Super Efficiency Score of the Cement Companies in Post Recession period

\begin{tabular}{clccc}
\hline SI No & Name of Company & Efficiency Score & Super Efficiency & Rank \\
\hline DMU1 & A C C Ltd. & 1 & 1.047 & 6 \\
DMU2 & Ambuja Cements Ltd. & 1 & 1.013 & 7 \\
DMU3 & India Cements Ltd. & .1 & 1.174 & 5 \\
DMU4 & J K Cement Ltd. & 1 & 1.182 & 4 \\
DMU5 & J K Lakshmi Cement & 1 & 1.248 & 2 \\
DMU6 & Prism Cement Ltd. & 1 & 1.306 & 1 \\
DMU7 & Ramco Cements Ltd. & .965 & ---- & 9 \\
DMU8 & Shree Cement Ltd. & 1 & 1.225 & 3 \\
DMU9 & Ultratech Cement Ltd & .943 & ------ & 8 \\
\hline
\end{tabular}


Table 5. Rank obtained by the Cement Companies during the Pre and Post Recession period

\begin{tabular}{clcc}
\hline SI No & Name of Company & Pre Recession Rank & Post Recession Rank \\
\hline DMU1 & A C C Ltd. & 4 & 6 \\
DMU2 & Ambuja Cements Ltd. & 5 & 7 \\
DMU3 & India Cements Ltd. & 8 & 5 \\
DMU4 & J K Cement Ltd. & 3 & 4 \\
DMU5 & J K Lakshmi Cement & 6 & 2 \\
DMU6 & Prism Cement Ltd. & 2 & 1 \\
DMU7 & Ramco Cements Ltd. & 7 & 9 \\
DMU8 & Shree Cement Ltd. & 1 & 3 \\
DMU9 & Ultratech Cement Ltd & 9 & 8 \\
\hline
\end{tabular}

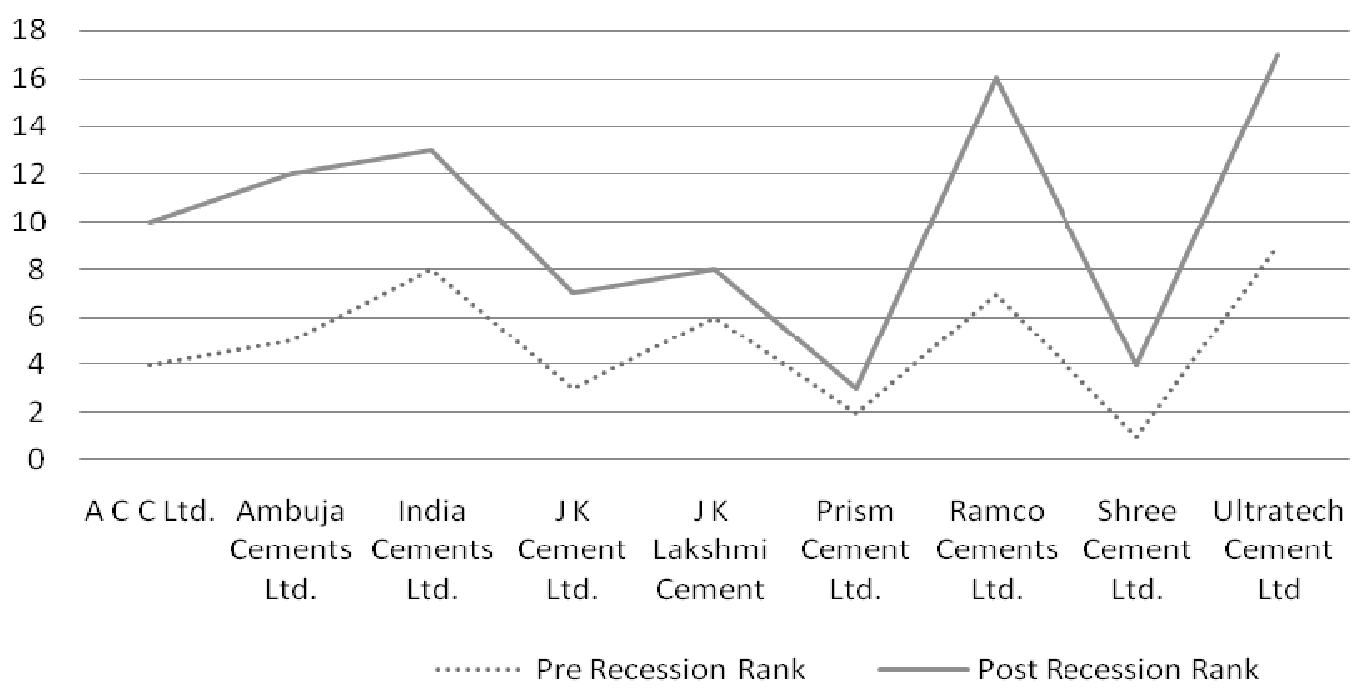

Figure 1. Graphical representation of the ranks obtained by the Cement companies during the Pre and Post period of recession

Table 6. Result of Spearman rank correlation

\begin{tabular}{rllrr}
\hline & & Pre_Rank & Post_Rank \\
\hline & \multirow{4}{*}{ Prerecession rank } & Correlation Coefficient & 1.000 & .633 \\
& & Sig. (2-tailed) &. & .067 \\
& & $\mathrm{~N}$ & 9 & 9 \\
& & Correlation Coefficient & .633 & 1.000 \\
& \multirow{3}{*}{ Post_Rank } & Sig. (2-tailed) & .067 &. \\
& & $\mathrm{~N}$ & 9 & 9 \\
\hline
\end{tabular}


utilized for the purpose. The descriptive statistics basically concentrates upon different parameters like mean, maximum, minimum of the five different input and output variables taken in this study during the Pre and Post period of recession which is shown in table 7 and 8 respectively.

\section{DISCUSSIONS}

It is observed from Table 2 that five out of nine cement companies are performing at super efficiency level (efficiency score $>1$ ) during the Pre recession period. Shree cement (with super efficiency score of 1.437) has obtained rank1 followed by Prism Cement and $\mathrm{J} \mathrm{K}$ Cement during the Pre recession period. An interesting phenomena is observed during the Post recession period where only two out of nine cement companies are performing below their efficiency level (score below 1). The companies are namely Ramco ltd and Ultratech cement. These two companies were also performing below their efficiency level during the Pre recession period also. Thus the number of companies performing at super efficiency level during the Post recession period has increased to seven from five out of nine during the post recession period compared to the pre recession period. Hence it is observed that there has been an overall increase of the performance efficiency of the Indian cement companies during the Post recession period compared to the Pre recession period. Prism cement ltd (with super efficiency score of 1.306) has obtained Rank 1 followed by J K Lakshmi Cement and Shree Cement (Rank 2 and 3 respectively) during the Post recession period.

It is observed that from the descriptive statistics in Table 6 and Table 7 that the mean of both the outputs i.e. the Sales and PBDIT has increased significantly during the Post

Table 7. Descriptive Statistics (mean) of Cement companies during Pre recession period

\begin{tabular}{ccccc}
\hline Variables & N & Minimum & Maximum & Mean \\
\hline Sales & 9 & 6998.00 & 57144.00 & 23983.1111 \\
PBDITA & 9 & 1640.00 & 17116.00 & 5635.2222 \\
Raw & 9 & 2199.00 & 18584.00 & 7577.1111 \\
Power & 9 & 1422.00 & 9328.00 & 4241.4444 \\
Compensation & 9 & 588.00 & 4368.00 & 1988.5556 \\
Valid N (listwise) & 9 & & & \\
\hline
\end{tabular}

Table 8. Descriptive Statistics (mean) of cement companies during Post recession period

\begin{tabular}{|c|c|c|c|c|c|}
\hline Variables & $\mathbf{N}$ & & Minimum & Maximum & Mean \\
\hline Sales & & 9 & 14919.00 & 86405.00 & 42826.4444 \\
\hline PBDITA & & 9 & 3517.00 & 24474.00 & 12228.4444 \\
\hline $\mathrm{RM}$ & & 9 & 12765.00 & 72331.00 & 36418.7778 \\
\hline Power & & 9 & 2049.00 & 11865.00 & 5584.5556 \\
\hline Compensation & & 9 & 2281.00 & 14721.00 & 7775.3333 \\
\hline Valid N (listwise) & & 9 & & & \\
\hline
\end{tabular}


recession period compared to the Pre recession period. The mean (average) of the Sales and PBDITA of the 9 cement companies has increased by $79 \%$ and $117 \%$ respectively during the post recession period compared to the pre recession period which is a drastic increase. The mean of the other three input variables of nine cement companies have also increased during the Post recession period compared to the Pre recession period. Hence we can safely assume that recession had little impact on the cement industry.

It can be observed from Table 8 that the spearman rank correlation is .633 which is greater than .50. Spearman rank correlation is basically utilized so as understand if there was significant or insignificant correlation existing between the ranks obtained by the Cement companies during the Pre and Post period of recession. The result of .633 (>.50) signifies that there has not been much significant difference between the ranks obtained by the Cement companies during the Pre and Post period of recession. Thus we can safely say that recession didn't have much of an impact on the Indian cement industry.

\section{CONCLUSIONS}

It can be observed from the above analysis that recession had a little impact on the performance of the cement industry in Indian scenario. Infact if we investigate into the average of the output variables taken in our study it can be deduced that the cement industry performed well during the Post recession period compared to the Pre recession period. The spearman rank correlation results also points to the same direction. An effort has been made to formulate the linear program for the input and outputs taken for the study so as to compute the efficiency of the cement industry in Indian scenario during the Pre and Post period of recession. It is also observed from the study that the number of companies working at super efficiency level has increased during the Post recession period compared to the Pre recession period. Hence it can be concluded from the above discussion that recession had little impact on the performance efficiency on the Indian Cement industry when the entire world was facing the negative effect of the recession.

One of the limitations of the present study is that it has been conducted taking two output variables and three input variables. If the variables are changed the result will also be affected. Hence the conclusion of the present study is based on the inputs and outputs taken for the study. The pre and the post recession period are taken for three years each. If the period taken into consideration for the study is increased then the result may also change.

\section{References}

Andersen, P., \& Petersen, N. C. (1993). A Procedure for ranking efficient units in Data envelopment analysis. Management Science, 39 (10), 1261-1264.

Banker, R., Charnes, A., \& Cooper, W. (1984). Some models for estimating technical and scale inefficiencies in data envelopment analysis. Management Science, 30, 1078-1092.

Charles, V., Kumar, M., Zegarra, L.F. \& Avolio, B. (2011). Benchmarking Peruvian Banks using Data Envelop Analysis. Journal of CENTRUM Cathedra, Business and Economic research Journal, 4 (2), 147-164. 


\title{
МЕРЕЊЕ ЕФИКАСНОСТИ ИНДИЈСКИХ КОМПАНИЈА ЗА ПРОИЗВОДЫУ ЦЕМЕНТА КОРИШЋЕЊЕМ АНАЛИЗЕ РАЗВОЈА ПОДАТАКА У ПЕРИОДУ ПРЕ И ПОСЛЕ РЕЦЕСИЈЕ
}

\author{
Arindam Banerjee
}

\begin{abstract}
Извод
Овај истраживачки рад је спроведен како би се мерила ефикасност компанија за произвдњу цемента у индијском окружење кориштењем концепта анализе података током периода пре и после почетка рецесије, односно током недавних глобалних превирања. У овој студији узета су у обзир два излаза (која су у вези са профитом и продајом) и три инпута везана за трошкове. У самом раду је коришћена повратна информација која улазна оријентисану промењиву прииближава мерној скали. За мерење ефикасности и резултата високих перформанси различитих компанија за производњу цемента, коришћен је развој алгоритма линеарног програмирања. У овом раду је извршен додатни покушај анализе постојања утицаја рецесије на индустрију цемента, користећи методу корелације ранга.
\end{abstract}

Кључне речи: анализа обухвата података, јединице одлучивања, ефикасност, рецесија, цемент, Индија

Charnes, A., Cooper, W., \& Rhodes, E. Making: Applications in Management and (1978). Measuring the efficiency of decision- Engineering, $1 \quad$ (2), 153-163. making units. European Journal of https://doi.org/10.31181/dmame1802160p

Operational Research, 2 (6), 429-444. Tandon, K., \& Malhotra, N. (2014). A

Feroz, E.H., Kim, S., \& Raab, R.L. Comparative evaluation of efficiency in the (2003). Financial Statement Analysis. A Data Indian Banking Industry using Data Envelop analysis approach. Journal of Envelopment Analysis. The IUP Journal of Operation Research Society, 54 (1), 48-58. Bank Management, 13 (2), 33-46.

Karimzadeh, M. (2012). Efficiency Tehrani, R., Megharagan, M.R., \& Analysis by using Data Envelop Analysis Golkani, M.R. (2012). A model for Model: Evidence from Indian Banks. evaluating financial performance of International Journal of Latest Trends in companies by Data Envelop Analysis- A case Finance and Economic Sciences, 2 (3), 228- study of 36 Corporations affiliated with 237.

Nandkumar, \& Singh, A. (2014). A Study of Technical Efficiency of Banks in India using DEA. IOSR Journal of Business and Management.16 (9), 37-43.

Popovic, M., Kuzmanovic, M., Savic, G. (2018). A comparative empirical study of Analytic Hierarchy Process and Conjoint analysis: Literature review. Decision private organization. International Business research, $5(8), 8-16$. 


\section{APPENDIX A}

Linear Program to measure the efficiency score of ACC ltd (Pre Recession period)

Min = theta;

$18584 * w 1+13898 * w 2+6118 * w 3+2340 * w 4+2759 * w 5+2199 * w 6+4189 * w 7+3363 * w 8+14744 * w 9<=18584 *$ theta; $7570 * w 1+9328 * w 2+3973 * w 3+2139 * w 4+1600 * w 5+1422 * w 6+2292 * w 7+1507 * w 8+8342 * w 9<=7570 *$ theta; $4368 * w 1+3834 * w 2+2186 * w 3+700 * w 4+834 * w 5+588 * w 6+1159 * w 7+784 * w 8+3444 * w 9<=4368 *$ theta; $49467 * w 1+57144 * w 2+19694 * w 3+10237 * w 4+7692 * w 5+6998 * w 6+12953 * w 7+10502 * w 8+41161 * w 9$ >=49467; $9979 * w 1+17116 * w 2+4083 * w 3+1720 * w 4+1640 * w 5+1905 * w 6+3158 * w 7+3337 * w 8+7779 * w 9>=9979$; $\mathrm{w} 1+\mathrm{w} 2+\mathrm{w} 3+\mathrm{w} 4+\mathrm{w} 5+\mathrm{w} 6+\mathrm{w} 7+\mathrm{w} 8+\mathrm{w} 9=1$ $\mathrm{w} 1>=0 ; \mathrm{w} 2>=0 ; \mathrm{w} 3>=0 ; \mathrm{w} 4>=0 ; \mathrm{w} 5>=0 ; \mathrm{w} 6>=0 ; \mathrm{w} 7>=0 ; \mathrm{w} 8>=0 ; \mathrm{w} 9>=0$;

\section{APPENDIX B}

Linear Program to measure the Super efficiency score of ACC ltd (Pre Recession period) Min $=$ theta;

$18584 * w 1+13898 * w 2+6118 * w 3+2340 * w 4+2759 * w 5+2199 * w 6+4189 * w 7+3363 * w 8+14744 * w 9<=18584 *$ theta; $7570 * w 1+9328 * w 2+3973 * w 3+2139 * w 4+1600 * w 5+1422 * w 6+2292 * w 7+1507 * w 8+8342 * w 9<=7570 *$ theta; $4368 * w 1+3834 * w 2+2186 * w 3+700 * w 4+834 * w 5+588 * w 6+1159 * w 7+784 * w 8+3444 * w 9<=4368 *$ theta; $49467 * w 1+57144 * w 2+19694 * w 3+10237 * w 4+7692 * w 5+6998 * w 6+12953 * w 7+10502 * w 8+41161 * w 9$ >=49467; $9979 * w 1+17116 * w 2+4083 * w 3+1720 * w 4+1640 * w 5+1905 * w 6+3158 * w 7+3337 * w 8+7779 * w 9>=9979$; $\mathrm{w} 2+\mathrm{w} 3+\mathrm{w} 4+\mathrm{w} 5+\mathrm{w} 6+\mathrm{w} 7+\mathrm{w} 8+\mathrm{w} 9=1$; $\mathrm{w} 2>=0$; 3 >=0; w4 >=0; w5 >=0; w6 >=0; w7 >=0; w8 >=0; w9 >=0; 


\section{APPENDIX C}

Efficiency Output using Lingo of ACC ltd during the Pre Recession period (Related to Appendix A)

Global optimal solution found. objective value:

Total solver iterations:
1.000000

4

$$
\begin{gathered}
\text { Reduced Cost } \\
0.000000 \\
0.000000 \\
0.000000 \\
0.1473013 \\
0.1090077 \\
0.8559951 \mathrm{E}-01 \\
0.7145582 \mathrm{E}-01 \\
0.6094005 \mathrm{E}-01 \\
0.000000 \\
0.2827253 \\
\text { Dual } 1510 \mathrm{P} \\
-1.000000 \\
0.000000 \\
0.1321004 \mathrm{E}-03 \\
0.000000 \\
-0.1837809 \mathrm{E}-04 \\
-0.1277062 \mathrm{E}-04 \\
0.3654695 \mathrm{E}-01 \\
0.000000 \\
0.000000 \\
0.000000 \\
0.000000 \\
0.000000 \\
0.000000 \\
0.000000 \\
0.000000 \\
0.000000
\end{gathered}
$$




\section{APPENDIX D}

Super Efficiency Output using Lingo of ACC ltd during the Pre Recession period (Related to Appendix B)

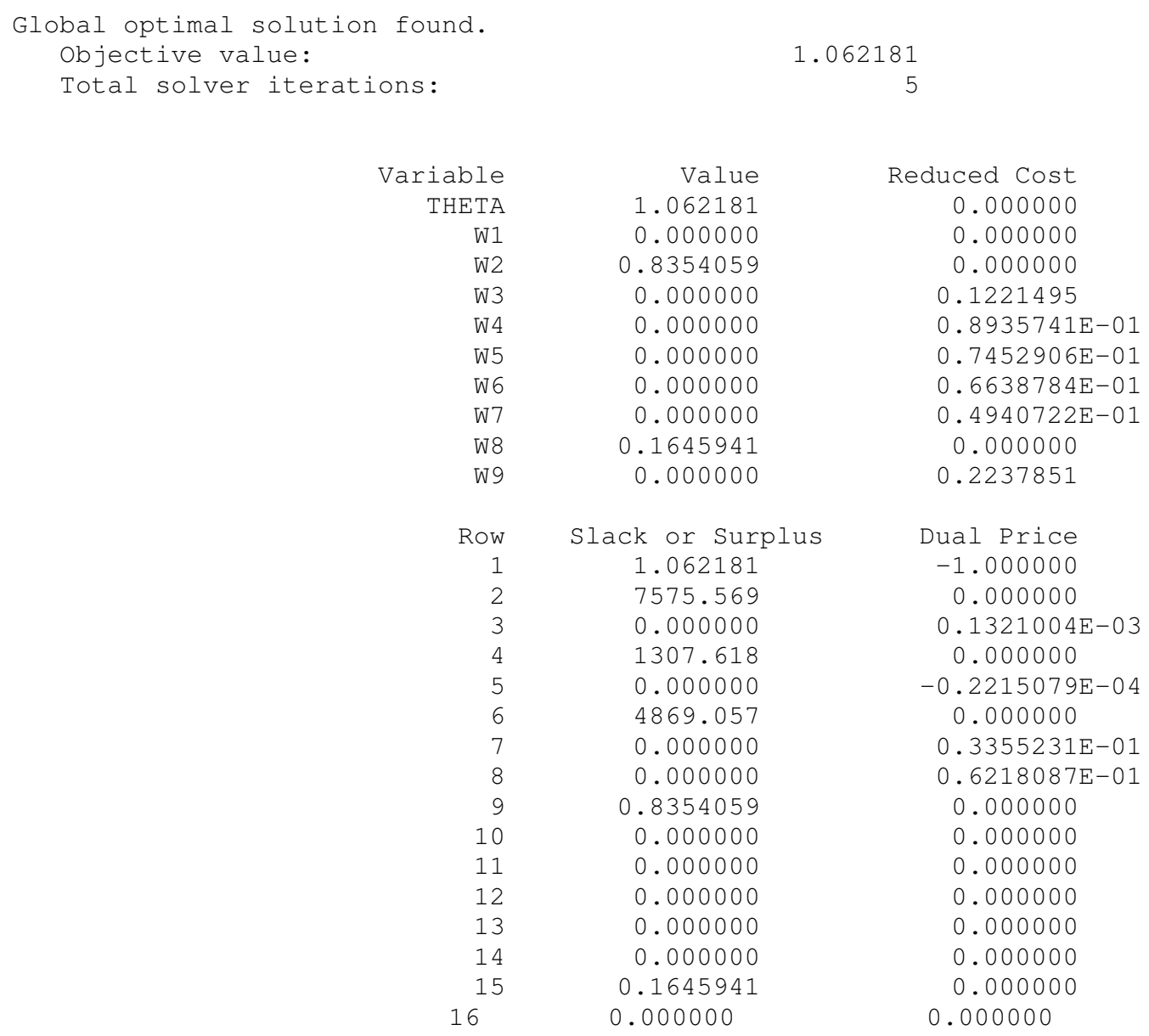

